\title{
REVITALISASI KAWASAN CITRA NIAGA SAMARINDA
}

\author{
Irsan Gazali \\ Magister Arsitektur, Program Pascasarjana, Universitas Katolik Parahyangan, Bandung, \\ Jl. Merdeka, No. 30, Bandung - Indonesia \\ Email: irsangazali91@gmail.com
}

\begin{abstract}
Abstrak
Arena promosi dan pusat perbelanjaan selanjutnya disebut Citra Niaga merupakan ikon kota Samarinda yang dibangun pada tahun 1984. Desain Citra Niaga diarahkan kepada konsep "pasar malam" yang menjadikan Citra Niaga berfungsi ganda sebagai ruang usaha dan tempat rekreasi publik yang aktraktif. Namun saat ini ikon kota Samarinda ini dirasa sepi karena ditinggal oleh pengunjungnya. Terdapat isu lemahnya kualitas ruang publik yang menyebabkan Citra Niaga tidak mampu bertahan, Citra Niaga saat ini dirasa belum memenuhi kualitas atau standar menjadi sebuah ruang publik yang baik. Terdapat kriteria normatif atau aspek yang harus diperhatikan dalam merancang suatu ruang publik (issue of concern) yaitu keamanan, keselamatan, kesehatan, daya tarik, kenyamanan, aksesibilas, dan keindahan. Dan untuk mencapai kriteria tersebut terdapat komponen yang harus diatur (scope of issues). Metode yang digunakan dalam penelitian ini yakni bersifat deskriptif kualitatif berdasarkan studi dilapangan dan bukti konkret. Pendekatan yang dilakukan berlandas pada teori revitalisasi dan teori perancangan ruang publik yang baik. Temuan studi akan menyimpulkan bahwa dalam memenuhi standar, kualitas suatu ruang publik harus memenuhi kriteria normatif sehingga diharapkan ruang publik tersebut mampu bertahan. Lalu konsep revitalisasi disini berperan sebagai upaya dalam memvitalkan kembali Citra Niaga tersebut.
\end{abstract}

Kata kunci: citra niaga, ikon, kota, ruang publik, revitalisasi

\begin{abstract}
Title: Revitalization of Citra Niaga Samarinda

Arena promotions and shopping centers nowadays called Citra Niaga as an icon of the capital of Samarinda, which was built in 1984. The design of Citra Niaga is directed to the concept of "Night Market" which makes Citra Niaga as a business space and recreation areas for the attractive public. But in a fact, the icon of Samarinda is not desirable again by the public because they have an issue that makes this icon become weak and has not good quality or as a good public space standardization (Issue of Concern), such as security, safety, health, attraction, comfort, accessibility and also raciness . And to comply those criteria, it should be have good components (Scope of Issue), for this research it can be used qualitative descriptive method it based on the fact in the field and also the real evidence. This approach based on revitalization theory and good space public theory. For the conclusion, the standardization, a space of quality must have normative criteria so a space public can be survive. So that, this functioned as revitalization concept in effort to revitalization Citra Niaga.
\end{abstract}

Keywords: citra niaga, icon, city, publik space, revitalization 


\section{Pendahuluan}

Kota Samarinda, ibukota provinsi Kalimantan Timur memiliki kompleks perbelanjaan yang diberi nama Arena Promosi dan Pusat Perbelanjaan Citra Niaga. Lokasinya adalah di atas tanah milik negara di salah satu pusat kota, seluas 2,7 hektar. Arena Promosi dan Pusat Perbelanjaan Citra Niaga selanjutnya disebut sebagai Citra Niaga dibangun pada tahun 1984. Pada awalnya didirikan untuk peremajaan kawasan sekitar. Kemudian diinterpetasikan sebagai usaha untuk mengubah citra dan wajah suatu kawasan tua, kumuh, padat, buruk, kotor, tidak terukur, menjadi kawasan perdagangan baru yang fungsional dan berestetika.

Proyek pembangunan Citra Niaga pada akhirnya menjadi proyek percontohan nasional pembangunan sektor informal dan pada tahun 1989 mendapatkan penghargaan prestisius yang diberikan setiap 3 tahun sekali sejak tahun 1977 oleh The Honour Aga Khan yang berkedudukan di Jenewa, Swiss. Aga Khan Award diberikan kepada karyakarya profesional di bidang arsitektur yang bernafaskan budaya Islam dan kepada konsepsi bangunan yang diidentifikasikan mampu memberi jawaban terhadap kebutuhan penduduk muslim melalui penyajian arsitektur yang menarik. Citra Niaga telah menjadi kebanggaan kota Samarinda, propinsi Kaltim dan bahkan pemerintah pusat, selama bertahun-tahun.

Desain Citra Niaga diarahkan kepada konsep "Pasar Malam" yang menjadikan Citra Niaga berfungsi ganda, sebagai ruang usaha dan juga berfungsi sebagai tempat rekreasi publik yang aktraktif.
Secara keseluruhan Citra Niaga ini berhasil menciptakan integrasi sosial yang baik, antara masyarakat pedagang mampu dikalangan masyarakat pengunjung dari semua lapisan. Seiring berjalannya waktu ternyata tidak membuat kawasan ini mampu mempertahankan jati dirinya sebagai kawasan publik yang memiliki arsitektur yang dapat dibanggakan. Sebaliknya Citra Niaga berpotensi mengalami kemunduran, saat ini ruang publik yang menjadi kebanggan kota Samarinda ini mulai ditinggal oleh pengunjungnya.

Permasalahan muncul dimana Citra Niaga saat ini dirasa tidak mampu memenuhi standar kebutuhan yang masyarakat inginkan, Citra Niaga dirasa hanya seperti sebuah ruang komersil yang hanya terfokus pada nilai jual dan beli antara pedagang dan pembeli. Citra Niaga dirasa melupakan fungsi atau citacita sebagai ruang publik yang memiliki fungsi ganda yaitu area komersil dan wisata. Tidak adanya penambahan unsur baru yang seharusnya menjadi daya tarik masyarakat kota saat ini juga dirasa menjadi salah satu faktor dimana Citra Niaga akhirnya mengalami kemunduran. Mungkin pada eranya dulu Citra Niaga masih mampu diukur sebagai suatu ruang publik yang baik dan mewadahi aspirasi masyrakat, namun karena tuntutan zaman Citra Niaga akhirnya berpaling sebagai suatu ruang yang sifatnya hanya pro terhadap ruang komersil sehingga menjauhkannya dari masyarakat yang saat ini butuh hiburan yang bersifat wisata publik ditengah hiruk pikuknya kehidupan perkotaan.

Menurut Edy Darmawan (2005) ruang publik merupakan ruang yang seharusnya dapat mewadahi kepentingan publik atau masyarakat umum, misalnya 
melakukan komunikasi dengan kolega, pertemuan informal komunitas tertentu, bermain, jalan jalan, melepas lelah, melihat lihat taman dan penghijauan, sekedar melihat orang lewat atau memperhatikan kegiatan orang disekitar ruang tersebut, atau bisa jadi hanya nongkrong menyaksikan hiruk pikuk kota sambil makan makanan kecil dan minuman yang dibawa sendiri atau beli dari pedagang kaki lima didekatnya. Berdasarkan kriterianya ruang publik memiliki terninologi yang beragam.

Pengertian ruang publik yang baik menurut Carr (1992). adalah suatu tempat umum bagi masyarakat melakukan aktifitas rutin dan fungsional yang mengikat sebuah komunitas, baik dalam rutinitas normal dari kehidupan sehari-hari, maupun dalam perayaan yang periodik. Seiring dengan perkembangan zaman, ruang publik baik pada zaman dahulu maupun pada saat sekarang tetap berfungsi sebagai tempat bagi masyarakat untuk bertemu, berkumpul dan berinteraksi, baik untuk kepentingan keagamaan, perdagangan maupun membangun pemerintahan.

Kebanyakan produk perancangan arsitektur belum begitu memikirkan ruang publik karena mengedepankan desain ruang-ruang internal, estetika bentuk, kenyamanan, dan kenikmatan didalam ruang dan sebagainya. Kurangnya perhatian dalam masalah yang berkaitan dengan ruang-ruang publik, bagaimana menata terkait: keamanan, keselamatan, kesehatan, daya tarik, kenyamanan, aksesibilitas dan keindahan ruang publik tersebut. Hal ini menunjukkan bahwa pemahaman betapa pentingnya peran ruang publik masih belum begitu nyata. Padahal suatu ruang publik dapat memberikan karakter tersendiri bagi suatu kota, sosial masyarakatnya, kegiatan ekonomi, dll. Dengan adanya masalah ruang publik terhadap Citra Niaga tersebut muncullah konsep revitalisasi. Revitalisasi sendiri lahir dari upaya untuk memberdayakan sebuah kawasan ketika kawasan tersebut mulai menurun, karena ditinggalkan sebagian penduduknya sebagai akibat langsung dari perluasan aktifitas ekonomi, tekanan sosial dan atau dampak pembukaan daerah hunian baru di daerah pinggiran kota. Revitalisasi menumbuhkan dan mengembangkan aktifitas ekonomi kawasan. Selanjutnya, aktifitas ekonomi dijadikan sebagai generator kegiatan, sehingga upaya pemberdayaan, perawatan dan penguatan karakater kawasan dapat berlangsung dengan baik. Pengembangan aktifitas ekonomi dapat berarti menghidupkan kembali aktifitas yang pernah ada atau bahkan secara lebih kompleks merestrukturisasi aktifitas ekonomi kawasan.

Secara konseptual, revitalisasi merupakan usaha meningkatkan vitalitas (kehidupan) kawasan kota melalui peningkatan dan pembaharuan kualitas lingkungan, dengan mempertimbangkan aspek sosial budaya dan karakteristik kawasan. Artinya, pada hakekatnya revitalisasi tidak lain merupakan salah satu bentuk mekanisme peremajaan. Secara lebih komprehensif, bila dikaitkan dengan paradigma berkelanjutan, revitalisasi merupakan sebuah upaya untuk mendaur-ulang (recycle) aset perkotaan dengan tujuan untuk memberikan vitalitas baru, meningkatkan vitalitas yang ada atau bahkan menghidupkan kembali vitalitas yang pemah ada. Namun, dapat dipastikan tujuannya adalah untuk menciptakan kehidupan baru yang 
produktif serta mampu memberikan kontribusi positif pada kehidupan sosialbudaya dan terutama kehidupan ekonomi (kawasan) kota, menurut Martokusumo (2006)

Dengan adanya masalah tersebut maka penelitian ini akan mengungkapkan konsep revitalisasi dan ruang publik yang tepat untuk Citra Niaga baik Citra Niaga sebagai kawasan perdagangan maupun Citra Niaga sebagai arena wisata publik. Masalah tersebut kemudian dianalisa melalu pengamatan langsung dilapangan, studi literatur, maupun wawancara terhadap kemuan masyarakat terkait proses memvitalkan kembali Citra Niaga. Tujuan dari penelitian ini adalah menghidupkan kembali identitas Citra Niaga sebagai suatu ikon kota Samarinda, mengembalikan jati diri Citra Niaga sebagai ruang publik yang dicintai masyarakatnya, maka dengan hidupnya kembali Citra Niaga juga otomatis menghidupkan kembali semangat perekonomian pedagang yang saat ini dirasa begitu sepi.

\section{Metode Penelitian}

Pada dasarnya metode penelitian dilakukan dengan cara mengumpulkan data, menganalisanya dan menarik kesimpulan. Dan secara umum pendekatan dalam penyusunan laporan studi ini bersifat kualitatif yang berorientasi pada peremajaan (revitalisasi) Kawasan Citra Niaga Samarinda.

1. Pengumpulan data

a. Studi literatur

b. Pengamatan lapangan

c. Metode wawancara
2. Tahap analisis data

3. Tahap pembuatan model simulasi sebagai analisa terapan

4. Tahap penarikan kesimpulan

Secara lebih spesifik dirangkum sebagai berikut:

1. Melalui observasi lapangan (survei data primer), yaitu dengan pengamatan langsung terhadap kondisi objek studi.

2. Identifikasi preferensi masyarakat setempat terhadap fasilitas ruang publik yang menjadi objek studi meliputi permintaan masyarakat terhadap kondisi fisik kawasan seperti penyediaan fasilitas kawasan, serta kondisi non-fisik kawasan seperti jenis aktifitas yang diinginkan di taman.

3. Teknik pengumpulan data yang digunakan adalah teknik komunikasi dan pengamatan. Teknik komunikasi dilakukan dalam bentuk wawancara dengan nara sumber yang berkaitan baik secara langsung maupun tidak langsung. antara lain, pedagang, pengelola Citra Niaga, pihak Pemkot, masyarakat sekitar, pemilik ruko di Citra Niaga dan lain-lain. Teknik pengamatan dilakukan secara langsung oleh peneliti.

4. Pengolahan data dilakukan melalui proses auditing. Di mana data diaudit untuk mendapatkan kepastian data. Data yang diaudit kemudian dapat dipakai tanpa perubahan atau diubah dahulu atau dihentikan sama sekali. Hal ini untuk mendapatkan data yang absah.

5. Setelah data diolah kemudian dianalisis. Proses analisis dilakukan berupa respon perencanaan 
kawasan. Kemudian dari proses analisis dihasilkan konsep perencanaan yang di dalamnya juga berisi kesimpulan berupa uraian keseluruhan hasil penelitian.

\section{Kasus Studi}

Arena Promosi dan Pusat Perbelanjaan Citra Niaga selanjutnya disebut sebagai Citra Niaga dibangun pada tahun 1984. Pada awalnya didirikan untuk peremajaan kawasan sekitar. Kemudian diinterpetasikan sebagai usaha untuk mengubah citra dan wajah suatu kawasan tua, kumuh, padat, buruk, kotor, tidak terukur, menjadi kawasan perdagangan baru yang fungsional dan berestetika. Ini adalah sebuah usaha yang seringkali menimbulkan dampakdampak sosial karena penghuni lama yang tidak keberatan dengan kekumuhan tersebut, menjadi terusir dari tempat semula. Lokasi Citra Niaga terdapat pada gambar 1:

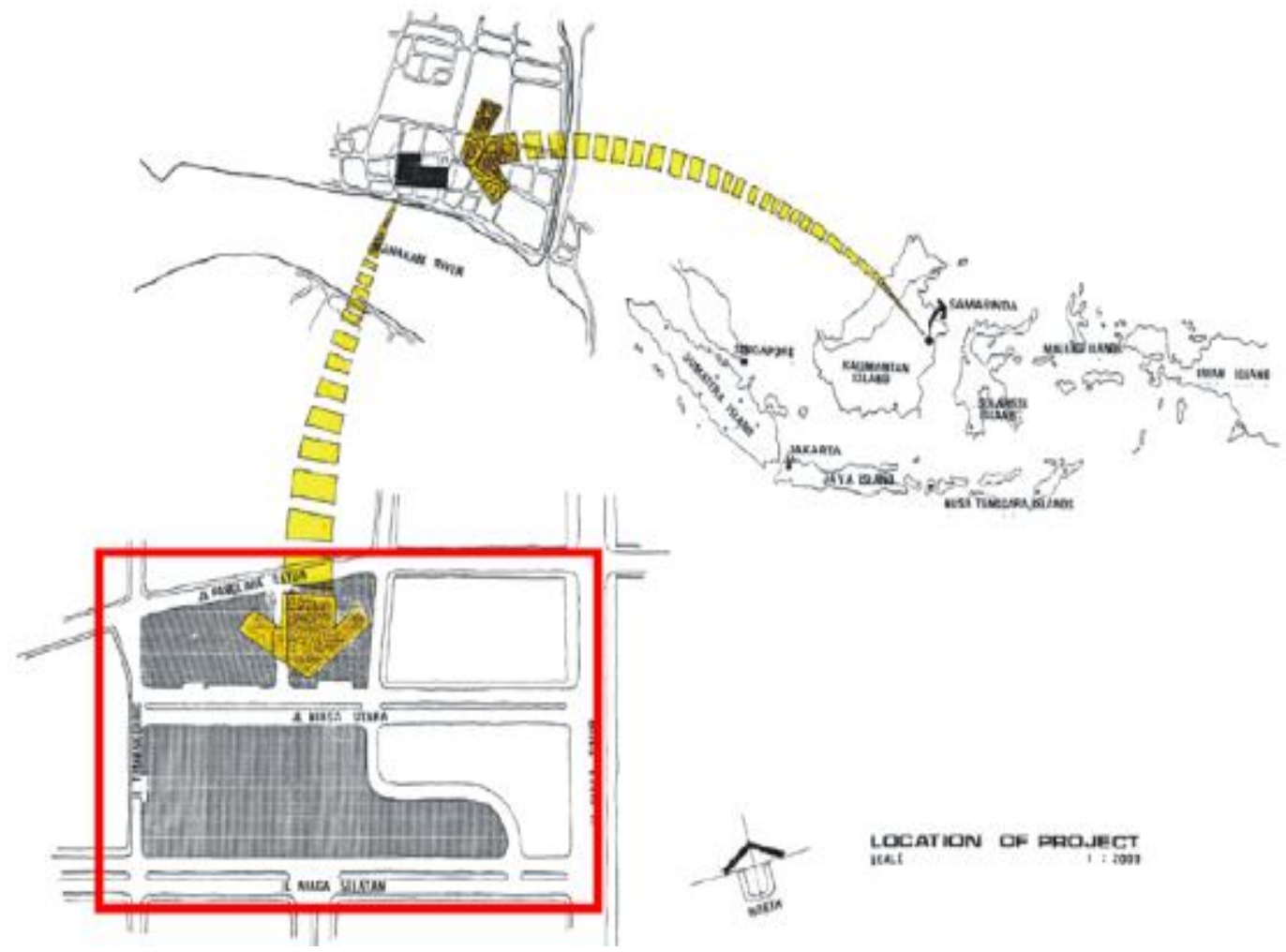

Gambar 1. Posisi kawasan citra niaga Samarinda

Sumber: Technical Reviuw Summary, Citra Niaga Urban Development, 1989

Proses pembangunan Citra Niaga dari kawasan kumuh hingga menjadi kawasan perdagangan ini melibatkan peran serta masyarakat pada seluruh aspek perencanaan, yang tercermin pada kerjasama yang nyata antara Pemerintah Pusat, Pemda Tk. I Kalimantan Timur (Sekarang sebutan menjadi Pemerintah Provinsi Kaltim), Pemerintah Daerah Tk. II Kotamadya Samarinda (sekarang 
Pemerintah Kota Samarinda), pihak swasta, pedagang, serta LPSM (Lembaga Pengembangan Swadaya Masyarakat). Hal ini dilakukan agar menghasilkan hubungan yang saling menguntungkan dan tidak mengganggu.

Citra niaga adalah suatu proyek yang menginginkan terciptnya suatau lingkungan yang bernuansa baru, segar dan dapat mendorong kegiatan ekonomi lemah, menengah dan kuat yang dapat saling menunjang. Dengan tekat bersama antara pemerintah yang memiliki power, pengusaha yang memiliki modal dan teknologi serta masyarakat yang mempunyai kemauan dan kehendak, maka terwujudlah proyek Citra Niaga ini sebagai pencermin pihak yang ikut membantu pihak yang lemah. Keberhasilan proyek Citra Niaga ini ditandai dengan diterimahnya " The Aga Khan Award For Architecture " dari yayasan Aga Khan di Jeneva Switzerland sebagai penghargaan tertinggi terhadap karya propesional dibidang arsitektur tahun 1989. Kemudian juga mendukung diperolehnya penghargaan adipura bagi Samarinda sebagai kota sedang terbaik tahun 1989. Berikut merupakan tower yang menjadi simbol Citra Niaga, gambar 2:

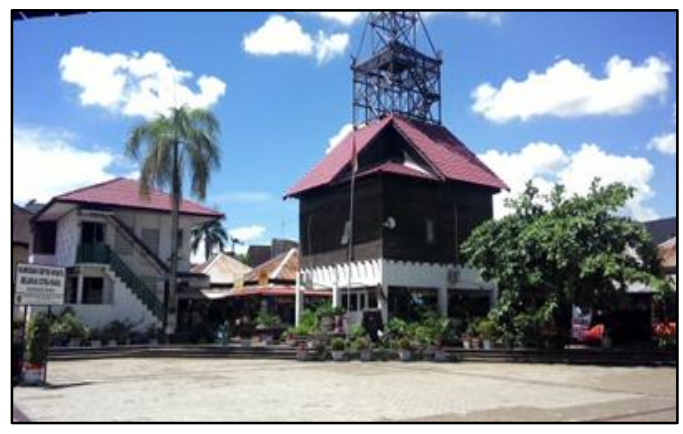

Gambar 2. Tower citra niaga Samarinda Sumber: Dokuementasi Pribadi, 2016
Citra Niaga dirancang untuk menyediakan ruang usaha bagi $60 \%$ pedagang golongan ekonomi lemah dan $40 \%$ pedagang golongan ekonomi kuat. Dan sebagian besar yang $60 \%$ tadi adalah PKL yang sebelum ada proyek ini sudah berdagang di lokasi ini. 1/3 dari bangunan komplek Citra Niaga yang terdiri dari 224 petak usaha diperuntukan PKL dihibahkan developer kepada Pemkot Samarinda, sehingga PKL tersebut menempati petaknya gratis. Hal ini memungkinkan karena diterapkan system "Subsidi Silang “, dimana pihak yang kuat membantu pihak yang lemah. Tata ruangnya disusun mengikuti konsep "Sarang Laba-Laba" yang tidak mengenal adanya bagian depan dan belakang, arah masuk dapat dilakukan melalui segala penjuru, sehingga semua pedagang berada pada posisi yang sama strategis dan tidak ada yang terisolasikan.Disain diarahkan kepada konsep "Pasar Malam" yang menjadikan Citra Niaga berfungsi ganda, sebagai ruang usaha dan juga berfungsi sebagai tempat rekreasi yang aktraktif. Secara keseluruhan Citra Niaga dulu berhasil menciptakan integrasi sosial yang baik, antara masyarakat pedagang mampu dikalangan masyarakat pengunjung dari semua lapisan. Gambar siteplan Citra Niaga, tampak kawasan Citra Niaga, kondisi plaza Citra Niaga, serta kondisi kios Citra Niaga yang dirasa sepi pengunjung diilustrasikan pada gambar 3 , gambar 4, gambar 5, gambar 6: 


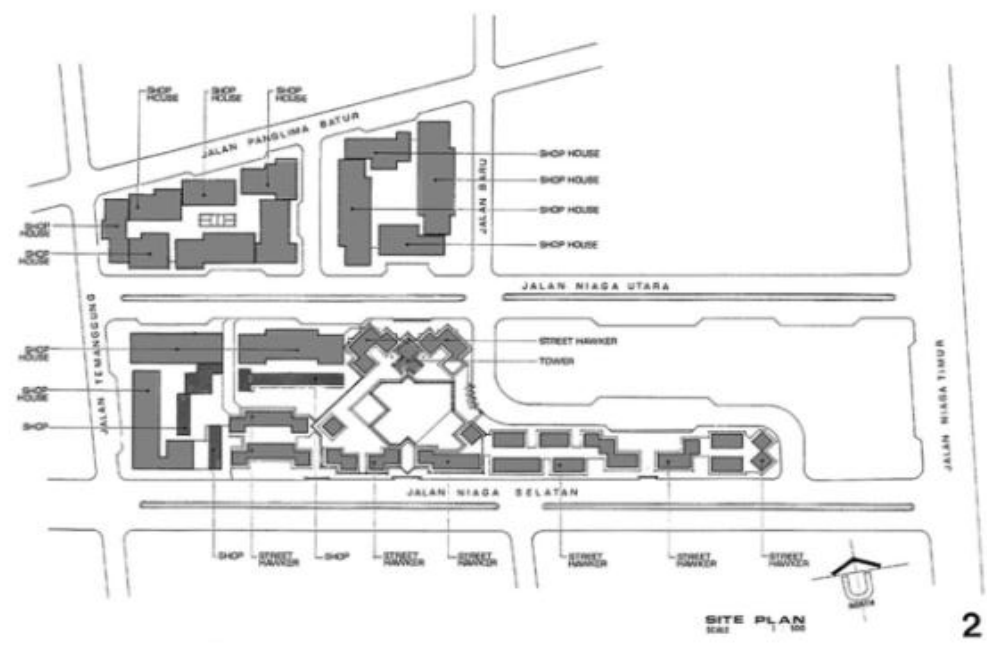

Gambar 3. Siteplan citra niaga

Sumber: Technical Reviuw Summary, Citra Niaga Urban Development, 1989

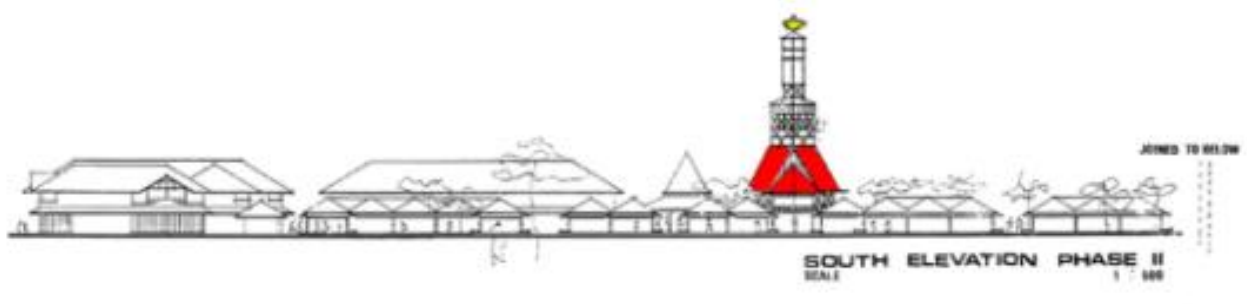

3
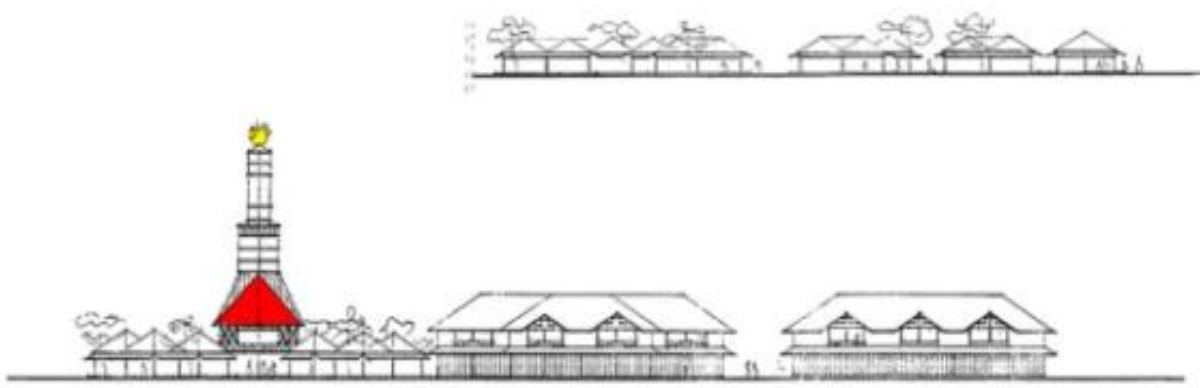

NORTH ELEVATION PHASE ॥

4

Gambar 4. Tampak kawasan citra niaga

Sumber: Technical Reviuw Summary, Citra Niaga Urban Development, 1989 


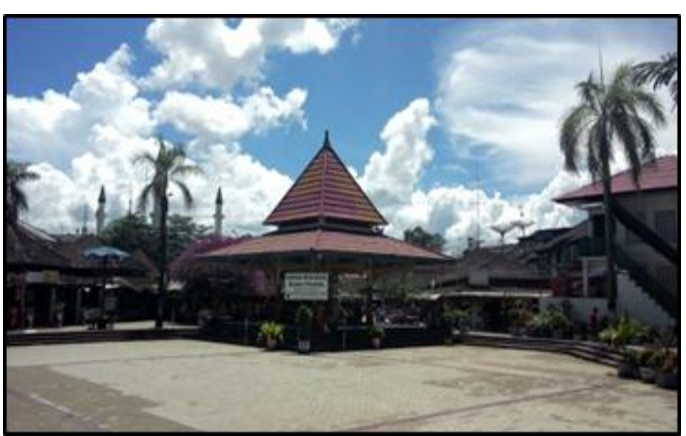

Gambar 5. Kondisi plaza citra niaga saat ini, sepi pengunjung

Sumber: Dokumentasi Pribadi, 2016

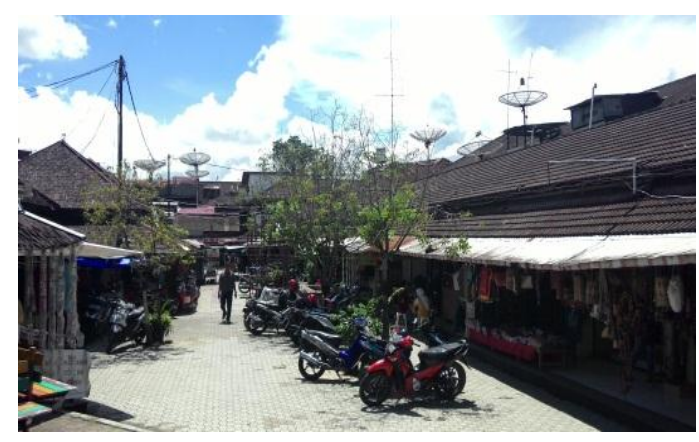

Gambar 6. Kondisi kios dagang citra niaga saat ini, sepi pengunjung

Sumber: Dokumentasi Pribadi, 2016

\section{Hasil Penelitian}

Analisis Data

Kriteria perancangan ruang publik bagi Citra Niaga didasarkan pada pertimbangan kriteria yang ditetapkan melalui rangkuman literatur yaitu keamanan, keselamatan, kesehatan, daya tarik, kenyamanan, aksesibilitas, dan keindahan. Prinsip revitalisasi pembentukan ruang publik Citra Niaga dilihat pada tabel 1 sebagai berikut:

\begin{tabular}{|c|c|c|c|}
\hline No. & Kriteria Perancangan & Prinsip Umum & Komponen yang Diatur \\
\hline 1. & Keamanan & $\begin{array}{l}\text { Visibilitas: aktifitas didalam } \\
\text { kawasan harus dapat dilihat } \\
\text { dengan mudah dari } \\
\text { lingkungan sekitar (memiliki } \\
\text { akses visual yang baik) untuk } \\
\text { menghindari adanya tindak } \\
\text { kejahatan didalam kawasan }\end{array}$ & Vegetasi penerangan \\
\hline 2. & Keselamatan & \begin{tabular}{lrr} 
Kawasan harus memiliki & \multicolumn{2}{c}{ memponen-komponen yang } \\
kompon \\
mampu menjamin penggua \\
terhindar dari bahaya \\
kecelakaan pada \\
beraktifitas
\end{tabular} & $\begin{array}{l}\text { Pagar pembatas sub-ruang } \\
\text { Jalur pejalan } \\
\text { Tangga/ramp } \\
\text { Penutup permukaan } \\
\text { signage }\end{array}$ \\
\hline 3. & Kesehatan & $\begin{array}{l}\text { Kawasan harus mampu } \\
\text { mengikat udara kotor (polusi) } \\
\text { agar iklim mikro yang } \\
\text { dihasilkan didalam kawasan } \\
\text { adalah iklim yang sejuk dan } \\
\text { menyehatkan }\end{array}$ & Vegetasi \\
\hline 4. & Daya Tarik & $\begin{array}{l}\text { Kawasan harus memiliki } \\
\text { ruang yang di jadikan pusat }\end{array}$ & Fasilitas aktifitas aktif \\
\hline
\end{tabular}




\begin{tabular}{|c|c|c|c|}
\hline & & $\begin{array}{l}\text { aktifitas pengguna dan mudah } \\
\text { terlihat dari lingkungan sekitar } \\
\text { agar mampu menjadi daya } \\
\text { tarik bagi warga setempat }\end{array}$ & \\
\hline 5. & Kenyamanan & $\begin{array}{l}\text { a. Kawasan harus memiliki } \\
\text { fasilitas untuk pengguna } \\
\text { melakukan aktifitasnya, } \\
\text { baik aktifitas aktif maupun } \\
\text { pasif } \\
\text { b. Kawasan } \\
\text { lingkungan fisik yang } \\
\text { mampu } \\
\text { kenyamanan } \\
\text { psikologis }\end{array}$ & $\begin{array}{l}\text { Vegetasi } \\
\text { Tempat duduk } \\
\text { Tempat sampah } \\
\text { Fasilitas aktifitas aktif }\end{array}$ \\
\hline 6. & Aksesibilitas & 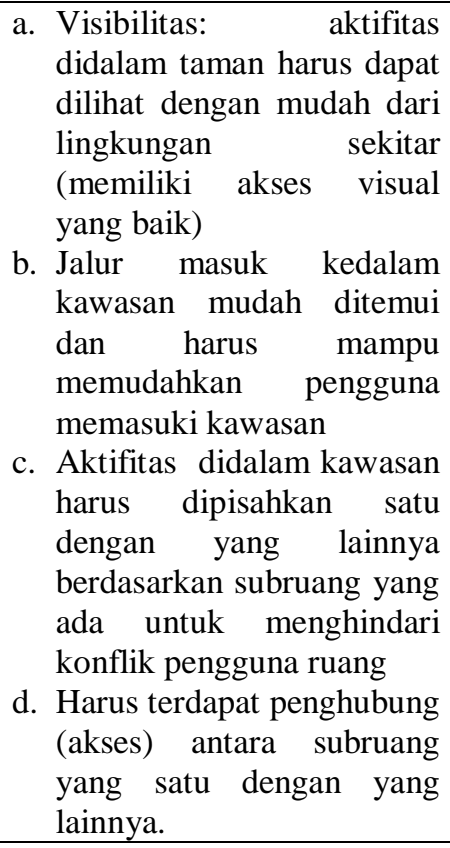 & $\begin{array}{l}\text { Jalur pejalan } \\
\text { Pembatas Sub-ruang }\end{array}$ \\
\hline 7. & Keindahan & $\begin{array}{l}\text { Kawasan harus memiliki } \\
\text { komponen-komponen } \\
\text { alamiah dan buatan yang } \\
\text { indah, beragam, menarik, } \\
\text { serta mampu memberikan } \\
\text { nuansa estetis pada kawasan }\end{array}$ & $\begin{array}{l}\text { Vegetasi } \\
\text { Elemen air }\end{array}$ \\
\hline
\end{tabular}

Tabel 1. Prinsip perancangan ruang publik

Sumber: Penelitian Tugas Akhir, Adriadi Dimastanto Melalui Rangkuman Literatur: Maslow (1943), Lang (1994), Tuscon (2007), Carr (1992), Majlis Perbandaran Seberang Perai (2007), Marcus \& Francis (1980), Eriawan (2003), Hou \& Lowber (2007), Vancouver (2007), Enger (2005), Rochester (2007), Bappeda Jabar, dan Hasil Analisis (2016).

Dari kriteria diatas maka terdapat merancang ruang publik, mulai dari komponen yang diatur. Kriteria penentuan akses masuk ke dalam perancangan komponen kawasan ini juga kawasan, pembagian sub-ruang, didasarkan pada urutan dalam pengaturan sirkulasi, penentuan penutup 
permukaan, dan yang terakhir adalah pengaturan komponen-komponen alamiah dan buatan. Untuk lebih jelasnya dapat dilihat pada. Prinsipprinsip umum perancangan komponen ruang publik dijelaskan pada tabel 2 sebagai berikut:

\begin{tabular}{|c|c|c|}
\hline No & Komponen & Indikator \\
\hline 1. & Vegetasi & $\begin{array}{l}\text { a. Keberadaan vegetasi tetap memungkinkan kawasan } \\
\text { terlihat dari lingkungan sekitar atau sebaliknya (terbuka) } \\
\text { b. Mampu menciptakan iklim mikro yang sejuk dan } \\
\text { menyehatkan } \\
\text { c. Mampu menciptakan nuansa yang nyaman bagi pengguna } \\
\text { d. Memiliki variasi bentuk, pola, dan warna }\end{array}$ \\
\hline 2. & Penerangan & Tersedia di berbagai lokasi pengguna beraktifitas \\
\hline 3. & Pembatas sub-ruang & Mampu memisahkan antaraktifitas \\
\hline 4. & Jalur Pejalan & $\begin{array}{l}\text { Berada dalam kondisi terawat tanpa kerusakan, Mampu } \\
\text { menghubungkan antaraktifitas }\end{array}$ \\
\hline 5. & Pagar & $\begin{array}{l}\text { Mampu memisahkan lingkungan taman dengan } \\
\text { lingkungan } \\
\text { eksternal }\end{array}$ \\
\hline 6. & Tangga /ramp & Mampu menghubungkan antar permukaan tidak sebidang \\
\hline 7. & Penutup permukaan & Berada dalam kondisi terawat tanpa kerusakan \\
\hline 8. & Signage & Tersedianya informasi penggunaan / pemanfaatan kawasan \\
\hline 9. & Fasilitas aktifitas aktif & $\begin{array}{l}\text { Terlihat dari lingkungan sekitar agar mampu menjadi daya } \\
\text { tarik, Mampu memenuhi keinginan pengguna beraktifitas } \\
\text { aktif }\end{array}$ \\
\hline 10. & Tempat duduk & Terletak di berbagai lokasi pengguna beraktifitas \\
\hline 11. & Tempat sampah & Terletak di berbagai lokasi pengguna beraktifitas \\
\hline 12. & Jalur masuk & Terletak di berbagai sisi taman dan mudah terlihat \\
\hline 13. & Elemen air & $\begin{array}{l}\text { Memiliki desain yang menarik dan mampu menciptakan } \\
\text { keindahan } \\
\text { lingkungan kawasan }\end{array}$ \\
\hline
\end{tabular}

Tabel 2. Prinsip perancangan komponen ruang publik

Sumber: Penelitian Tugas Akhir, Adriadi Dimastanto Melalui Rangkuman Literatur: Maslow (1943), Lang (1994), Tuscon (2007), Carr (1992), Majlis Perbandaran Seberang Perai (2007), Marcus \& Francis (1980), Eriawan (2003), Hou \& Lowber (2007), Vancouver (2007), Enger (2005), Rochester (2007), Bappeda Jabar, dan Hasil Analisis (2016)

\section{.Analisis komponen ruang publik Citra Niaga}

\section{Entrance}

Citra niaga menggunakan pola jaring laba-laba dalam desainnya sehingga akses masuk dan keluar kawasan merupakan multy entrance dan multy exit, sehingga pengunjung bebas masuk dan keluar melalui area manapun. Konsep multy entrance dan multy exit entrance sebenarnya merupakan konsep yang baik, namun pada kenyataan dilapangan terdapat kelemahan terhadap konsep ini yaitu masyarakat yang datang ke kawasan tidak mendapat pengalaman dalam mengitari kawasan karena ketika tujuan berbelanja barang telah selesai 
pengunjung langsung meninggalkan area kawasan tanpa sempat berjalan mengitari kawasan lain. Kondisi entrance dilihat pada gambar 7 berikut:

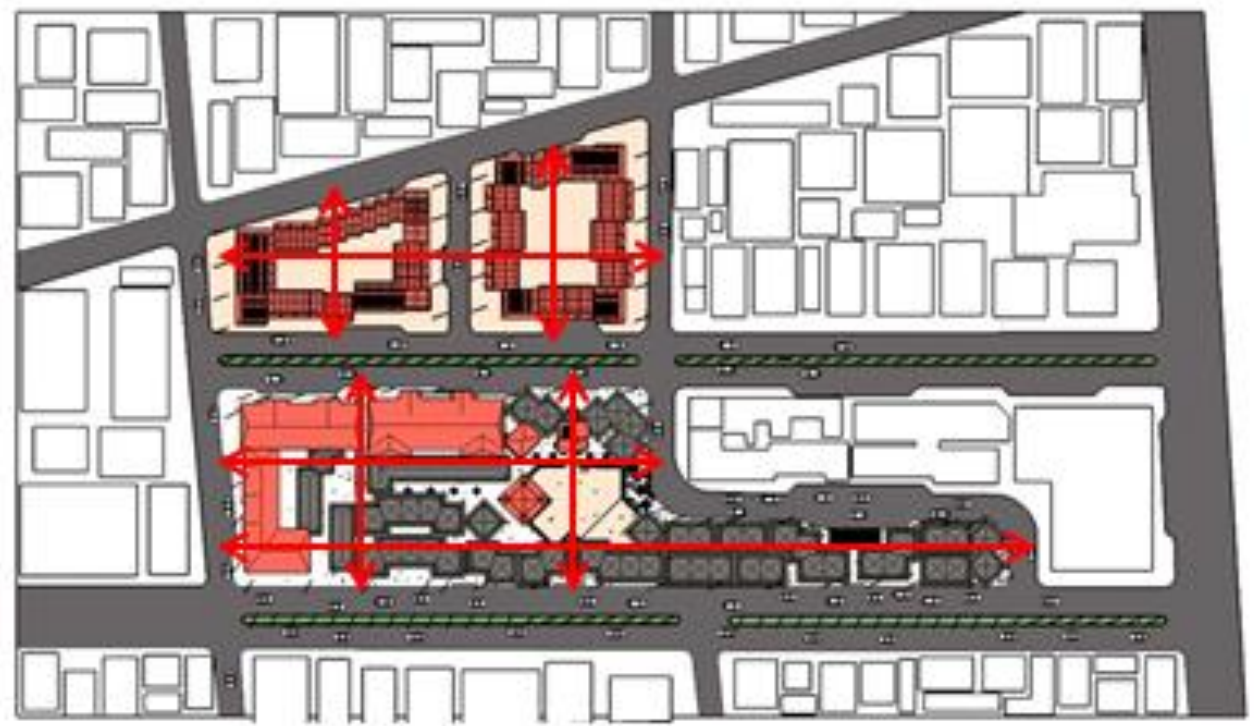

Gambar 7. Entrance citra niaga saat ini

Sumber: Hasil Analisis, 2016

\section{Zona Pedagangan}

Citra Niaga dibagi menjadi 3 zona, diantaranya kuning yaitu area perukoan, hijau yaitu area kios kecil, dan biru sebagai area toko pedagang, sementara plaza berada ditengah (center) kawasan.
Perlu ada perbaikan terkait zona perdagangan dikarenakan ada beberapa titik yang menjadi pusat keramaian dan ada beberapa titik yang sepi pengunjung. Berikut merupakan zona perdagangan Citra Niaga, gambar 8:

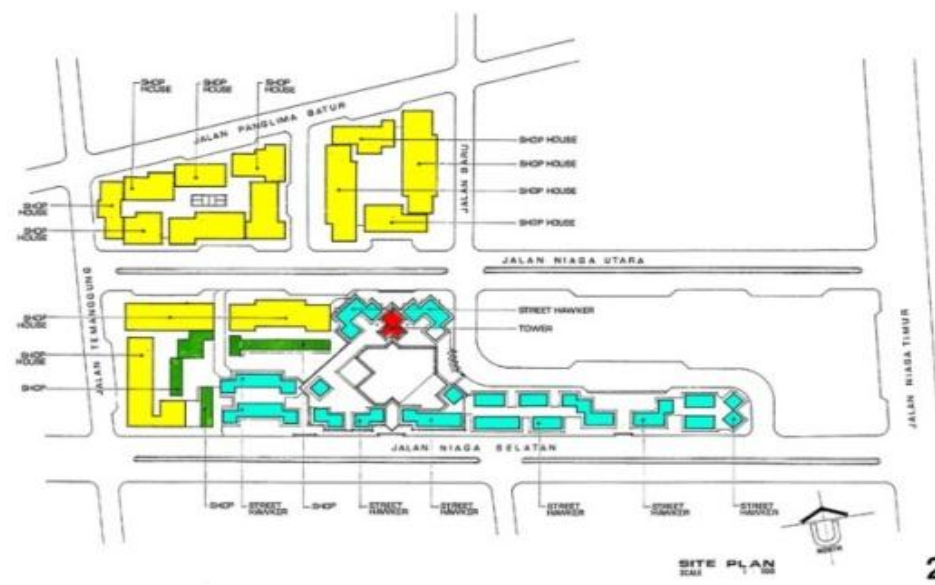

Gambar 8. Zona perdagangan citra niaga saat ini

Sumber: Technical Reviuw Summary, Citra Niaga Urban Development, 1989 


\section{Sub Ruang Aktifitas}

Zona merah (Aktif), merupakan area dimana transaksi perdagangan yang dirasa cukup rame dibanding zona yang lain. Zona kuning (Aktif Pasif), hal ini terlihat dari beberapa toko yang cukup rame dan ada beberapa yang sangat sepi bahkan telah ditutup. termasuk area plaza kawasan dirasa sangat sepi, hal tersebut dilihat dari pengamatan langsung dilapangan. Zona Biru (Pasif), merupakan area dimana transaksi perdagangan yang dirasa penulis cukup sepi hal ini terlihat dari pengamatan langsung dilapangan.

Perlu adanya penataan ulang terkait zona aktifitas dimana pusat keramaian ada pada zona merah, zona kuning, zona biru merupakan zona yang sepi. Terlampir pada gambar 9 sebagai berikut:

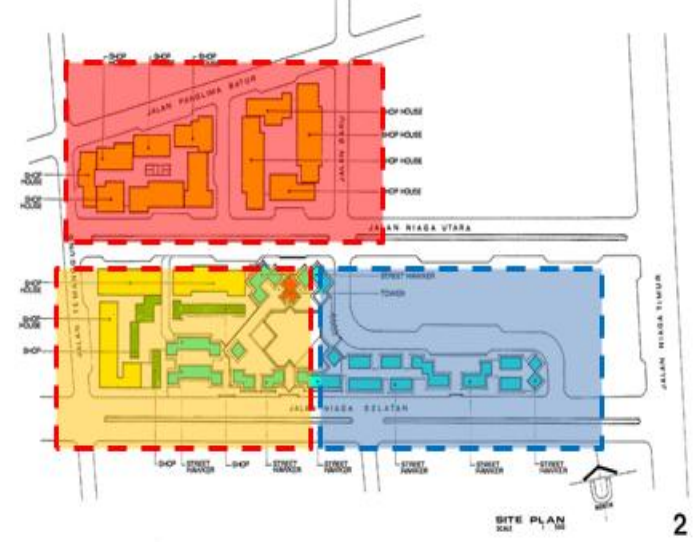

Gambar 9. Sub aktifitas perdagangan citra niaga

Sumber: Technical Reviuw Summary, Citra Niaga Urban Development, 1989

\section{Sirkulasi}

Citra Niaga merupakan suatu kawasan yang mempunya 2 fungsi yaitu wisata dan belanja. Sirkulasi pada kawasan ini menempatkan pejalan kaki sebagai unsur utama (active living). Jalur masuk baik pada area perukoan maupun area Citra Niaga menggunakan tangga guna mencegah pkl naik keatas trotoar. Tinggi anak tangga diasumsikan $14 \mathrm{~cm}$ dengan menggunakan bahan beton agar tidak licin. Jalur pejalan sebagai subruang sirkulasi disediakan sebagai penghubung setiap zona subruang yang ada. Serta antara subruang dengan jalur masuk. Pola sirkulasi Citra Niaga dilihat pada gambar 10:

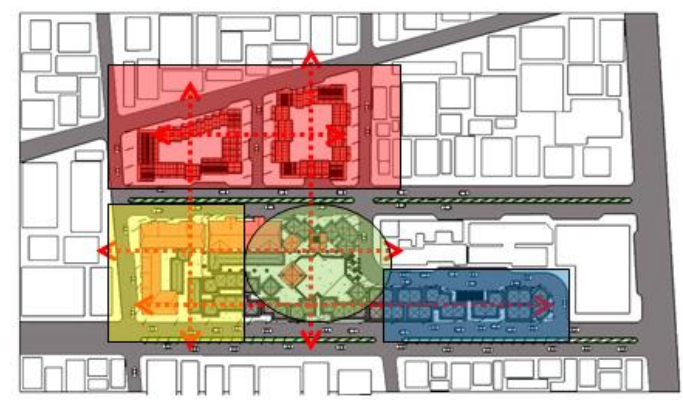

Gambar 10. Sirkulasi citra niaga

Sumber: Hasil Analisis, 2016

\section{Penutup Permukaan Citra Niaga}

Penutup permukaan citra niaga didominasi oleh paving block, kelemahan dari penutup permukaan ini adalah terasa gersangnya kawasan. Kombinasi dari rumput dan paving block dirasa cukup baik apabila diterapkan pada kawasan wisata dan belanja seperti ini. Mengingat rumput mampu memberikan kesan estetis terhadap pengunjung serta paving block merupakan material yang mampu memberi rasa aman terhadap pengunjung dikarenakan tidak licin. Kondisi penutup permukaan Citra Niaga terlampir pada gambar 11 dan gambar 12: 


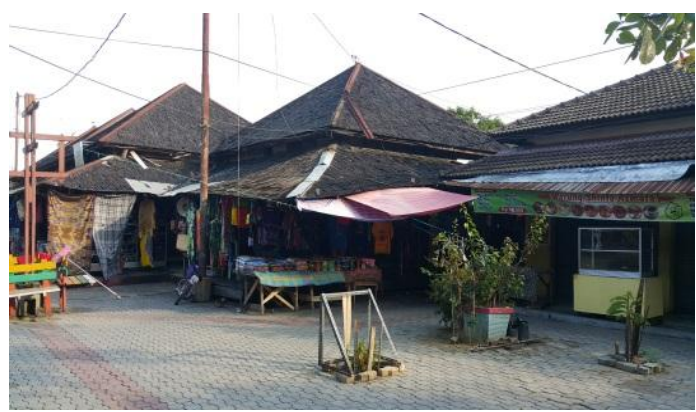

Gambar 11. Kondisi penutup permukaan citra niaga

Sumber: Dokumentasi Pribadi, 2016

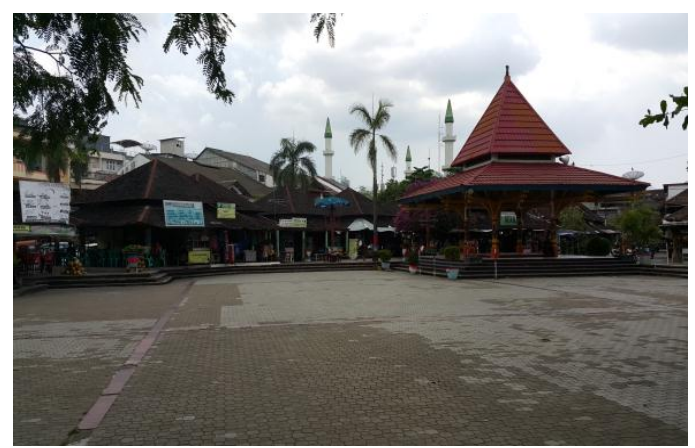

Gambar 12. Kondisi penutup permukaan citra niaga area plaza

Sumber: Dokumentasi Pribadi, 2016

\section{Komponen Vegetasi}

Belum ada penataan lansekap yang berarti pada kawasan. Tapak terasa gersang tanpa sentuhan hijau tanaman. Sepanjang tapak hanya terdapat sedikit pohon. Padahal untuk area perbelanjaan publik seperti ini lansekap memegang peranan penting sebagai nilai tambah yang jarang dijumpai pada mal-mal modern. Penataan lansekap yang optimal selain memberi kesan estetis juga memberikan kesejukan pada kawasan dan memberi kenyamanan bagi pengunjung. Kondisi vegetasi Citra Niaga terlampir pada gambar 13 dan gambar 14:

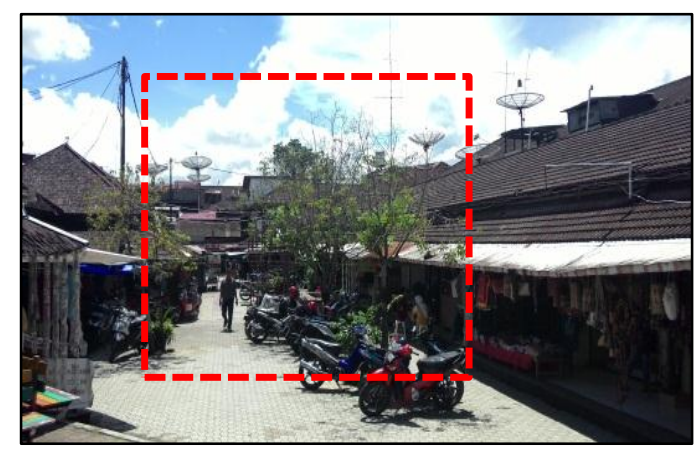

Gambar 13. Kondisi vegetasi citra niaga Sumber: Dokumentasi Pribadi, 2016

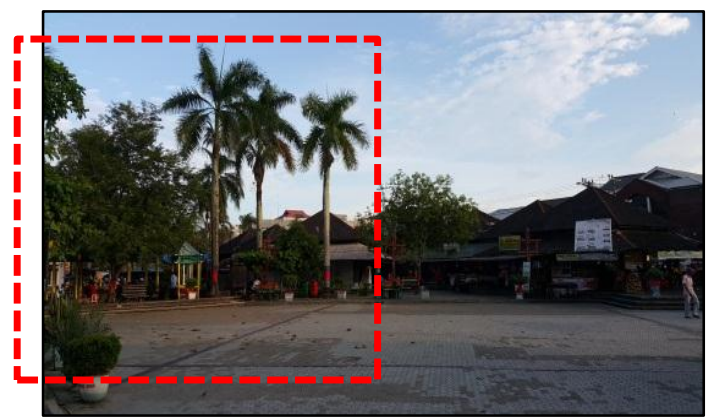

Gambar 14. Kondisi vegetasi citra niaga Sumber: Dokumentasi Pribadi, 2016

Belum adanya pentaan lansekap pada kawasan Citra Niaga. Kebanyakan pohon dan perdu hanya ditempatkan pada area sudut kawasan dan area plaza yang tidak tertata. Citra Niaga merupakan kawasan belanja dan hiburan rakyat maka untuk mengantisipasi panasnya cuaca disiang hari disediakan elemen peneduh pada setiap sisi kawasan yang merupakan jalur sirkulasi pejalan maupun diarea tempat duduk pengunjung.

Pembuatan kembali vegetasi hendaknya ditempatkan diseluruh bagian taman, namun dibatasi agar tidak menghalangi pandangan. Vegetasi disini juga berguna sebagai alternatf peredam panas matahari kepada pengguna kawasan. Penempatan vegetasi peneduh (jarak antar pohon) tetap memungkinkan 
keterbukaan pandangan dari lingkungan sekitar kawasan. Seperti pada gambar 15 berikut:

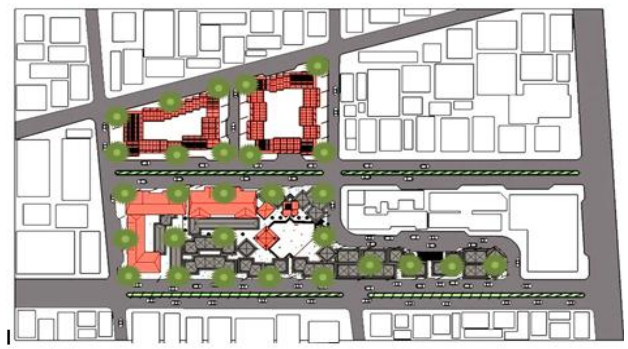

Gambar 15. Kondisi perletakan vegetasi baru citra niaga

Sumber: Hasil Analisis, 2016

\section{Penerangan}

Citra Niaga merupakan kawasan perdagangan yang dulunya buka sampai malam hari, dengan beberapa penerangan yang cukup baik. Akan tetapi saat ini Citra Niaga tidak lagi beroperasi dimalam hari, hanya perukoan area utara yang masih beroperasi karena ruko tersebut berhadapan langsung dengan akses jalan utama Panglima Batur. Sebaliknya pada area lain seperti kios dan toko yang berada dekat dengan plaza hampir semua tidak lagi buka, hal ini merupakan buntut dari sepinya pengunjung ruang publik tersebut. Kondisi penerangan citra niaga terlampir pada gambar 16 dan gambar 17 sebagai berikut:

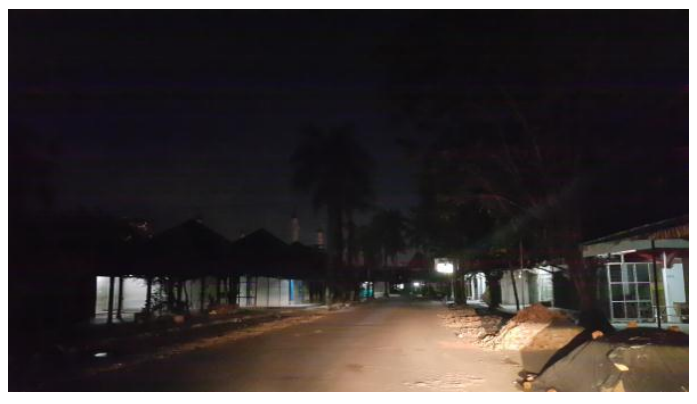

Gambar 16. Kondisi penerangan citra niaga malam hari

Sumber: Dokumentasi Probadi, 2016

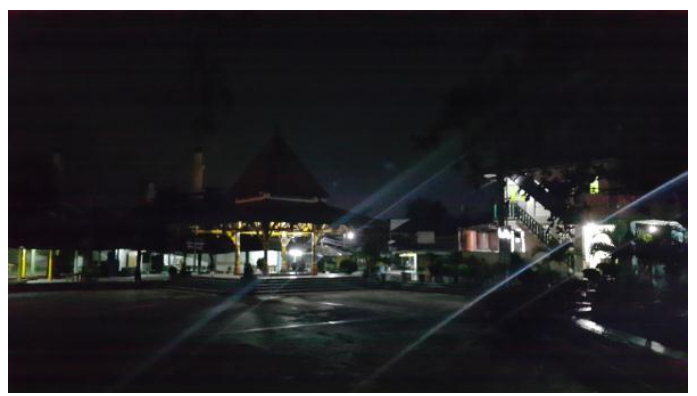

Gambar 17. Kondisi penerangan citra niaga malam hari area plaza

Sumber: Dokumentasi Pribadi, 2016

Untuk menghidupkan kembali kondisi Citra Niaga terkait penerangan maka akan dibuat penyelesaian pada gambar 18 sebagai berikut:

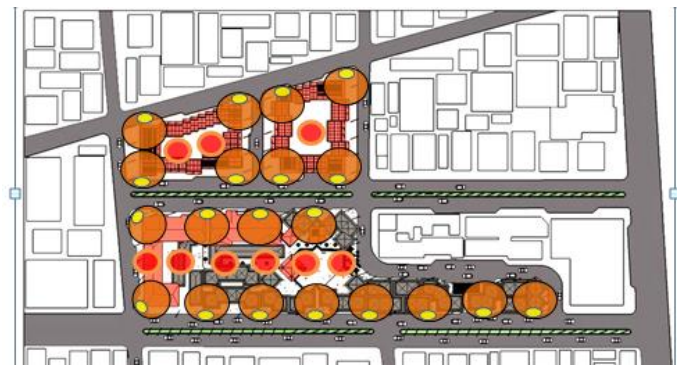

Gambar 18. Kondisi perletakan lampu penerangan baru citra niaga

Sumber: Dokumentasi Probadi, 2016

Seluruh bagian kawasan memperoleh pencahayaan termasuk sudut-sudut ruang pada kawasan. Lampu kawasan yang disediakan adalah lampu tinggi dan 
lampu rendah yang dilihat pada gambar 19 sebagai berikut:

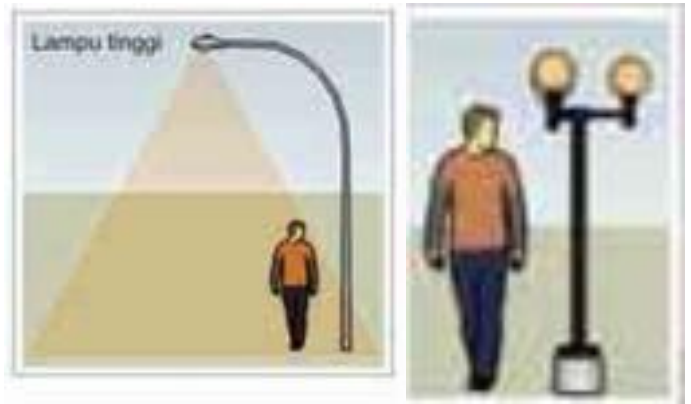

Gambar 19. Modul lampu penerangan citra niaga

Sumber: Gambar Tugas Akhir Adriadi Dimastanto, 2008

\section{Komponen Tempat Duduk dan Tempat Sampah}

Tempat duduk merupakan sesuatu yang vital karena dapat menjadi tempat berkomunikasinya individu yang mendatangi lokasi. Citra niaga tidak menyediakan tempat duduk yang cukup untuk menampung pengunjung, serta kurangnya kanopi untuk melindungi tempat duduk tersebut dari terik matahari. Begitu pula yang terjadi dengan tempat sampah, bahwa dari pengamatan sangat sedikit sekali spot yang menjadi tempat pembuangan sampah pada kawasan, padahal tempat sampah merupakan sesuatu yang sangat penting bagi area kawasan perdagangan seperti pada gambar 20 berikut ini:
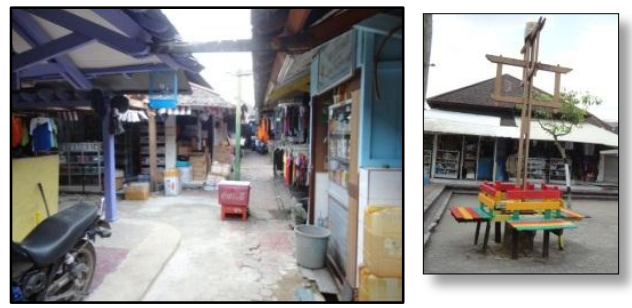

Gambar 20. Kondisi tempat duduk dan tempat sampah citra niaga

Sumber: Dokumentasi Pribadi, 2016
Signage

Sign memiliki beberapa fungsi penting bagi manusia. Secara ringkas, menurut SEGD (US Society of environmental Graphic Designer) fungsi sign adalah :

a. Sebagai alat untuk membantu manusia dengan cara mengarahkan,mengidentifikasi ruang atau struktur dan memberi informasi manusia dalam melakukan kegiatan dalam suatu ruang

b. Memperkuat kualitas lingkungan secara visual

c. Melindungi kepentingan umum

Pada kawasan Citra Niaga belum adanya signage yang jelas sehingga menyulitkan pengunjung untuk mengakses setiap detil tempat tersebut. Rambu yang ada hanyalah bersifat penamaan pada kawasan atau kios setempat. Padahal signage merupakan sesuatu yang penting mengingan Citra Niaga merupakan sebuah kawasan dengan area yang cukup luas. Kondisi signage kawasan Citra Niaga dilihat pada gambar 21 sebagai berikut :

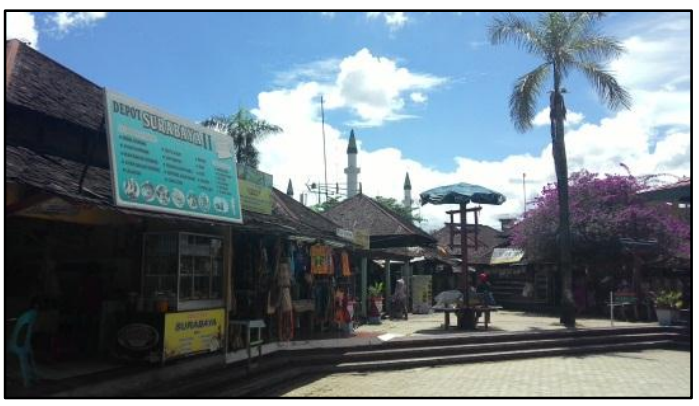

Gambar 21. Kondisi signage citra niaga Sumber: Dokumentasi Pribadi, 2016

\section{Temuan Studi}

Secara normatif, terdapat kriteria-kriteria atau aspek-aspek yang diperhatikan (issues of concern) dalam merancang 
ruang publik Citra Niaga, yaitu keamanan, keselamatan, kesehatan, daya tarik, kenyamanan, aksesibilitas dan keindahan. Untuk mencapai kriteriakriteria tersebut, terdapat komponenkomponen yang harus diatur (scope of issues) yaitu vegetasi, lampu penerangan, pembatas subruang, jalur pejalan, pagar, tangga/ramp, penutup permukaan, signage, fasilitas aktifitas aktif, tempat duduk, tempat sampah, jalur masuk dan elemen air.

Berdasarkan hasil penilaian terhadap Citra Niaga yang menjadi objek studi, secara umum belum memiliki kualitas yang baik. Citra Niaga memiliki kualitas lingkungan fisik dibawah harapan pedagang maupun masyarakat yang datang, dan temuan dari hasil penilaian berdasarkan kriteria kualitas kawasan adalah sebagai berikut: Citra Niaga memiliki kelemahan dari segi keamanan ruang publik, kesehatan lingkungan, kenyamanan, serta keindahan. Citra Niaga memiliki kelebihan pada daya tarik bangunan yang ada dikawasan dengan mengadopsi kultur adat setempat serta jaminan keselamatan beraktifitas yang dirasa telah cukup baik.

Karateristik masyarakat setempat selaku pengunjung potensial Citra Niaga yang ada adalah laki-laki dan perempuan pada usia dewasa (21-60 tahun). Dengan golongan pendapatan menengah kebawah.

Persepsi masyarakat melalui teknik wawancara dan pengamatan langsung dilapangan terhadap pengunjung maupun penjual selaku pengguna Citra Niaga berdasarkan kriteria perancangan ruang publik adalah sebagai berikut: Citra Niaga merupakan kawasan publik yang dirasa cukup aman, tetapi muncul kekhawatiran tersendiri dimana saat ini banyak preman dan gelandangan yang sering berdiam pada gazebo plaza kawasan baik siang hari maupun malam hari. Citra Niaga belum memiliki karakteristik lingkungan kawasan publik yang sehat. Citra Niaga saat ini dipandang biasa saja ditinjau dari segi kemenarikan secara umum. Hal yang mampu memberi daya tarik hanya tower maupun gazebo yang terdapat pada plaza Citra Niaga. Sedangkan hal yang tidak menarik pada kawasan adalah fasilitasnya yang dirasa belum memadai dan tidak terawat. Ditinjau dari segi kenyamanan secara umum, Citra Niaga saat ini belum memberikan rasa nyaman bagi penggunanya. Dan jika ditinjau dari segi kelengkapan fasilitas, Citra Niaga juga dinilai belum memiliki fasilitas yang menjadi kebutuhan masyarak Kota saat ini. Secara umum Citra Niaga tidak memiliki hambatan aksesibilitas fisik secara umum. Begitu pula dengan aksesibilitas didalam taman, yang dinilai baik dalam hal kebebsasan beraktifitas. Pengunjung saat ini menilai bahwa Citra Niaga tidak memiliki lingkungan dengan nuansa keindahan.

Persespsi masyarakat yang disimpulkan melalui teknik wawancara dan pengamatan langsung dilapangan terhadap pengunjung maupun penjual selaku pengguna Citra Niaga berdasarkan kriteria perancangan ruang publik adalah sebagai berikut: Untuk menciptakan lingkungan ruang publik yang aman, pengunjung Citra Niaga membutuhkan vegetasi peneduh yang tidak menutupi kawasan, serta penyediaan lampu penerangan diberbagai titik lokasi kawasan. Agar terjaminnya keselamatan beraktifitas, Citra Niaga memerlukan adanya pemisahan aktifitas yang satu dengan yang lainnya didalam kawasan, penyediaan penutup permukaan yang 
datar dan terawat dengan baik, penyediaan jalur pejalan yang terawat dengan baik, serta penyediaan papan informasi pada taman sebagai petunjuk keselamatan. Untuk menciptakan lingkungan publik yang sehat, Citra Niaga membutuhkan penyediaan vegetasi peneduh untuk mengurangi polusi. Agar Citra Niaga memiliki daya tarik sebagai tempat berinteraksi, Citra Niaga memerlukan penyediaan fasilitas aktifitas aktif yang mudah terlihat dari luar untuk melengkapi kebutuhan masyarakat Kota yang semakin komplek. Untuk menciptakan lingkungan publik yang mendukung kenyamanan beraktifitas, Citra Niaga membutuhkan penyediaan vegetasi peneduh, penambahan tempat duduk, penyediaan tempat sampah, serta penyediaan fasilitas aktifitas aktif. Untuk mendukung aksesibilitas Citra Niaga, dilakukan pemisahan antara aktifitas yang satu dengan yang lainnya, penyediaan jalur pejalan sebagai penghubung antar sub-ruang, penyediaan jalur masuk yang mudah terlihat, penyediaan jalur masuk disetiap sisi, serta penyediaan vegetasi yang tidak menutupi kawasan untuk mendukung aksesibilitas visual. Citra Niaga membutuhkan penyediaan vegetasi yang variatif untuk menciptakan keindahan pada kawasan. Penyediaan hiasan air pada kawasan akan menciptakan gairah kembali masyarakat untuk kembali berkunjung ke Citra Niaga.

\section{Kesimpulan}

Ruang publik kota merupakan kebutuhan penting masyarakat, karenanya indikator perancangan ruang publik secara normatif terkait kemanan, keselamatan, kesehatan, daya tarik, kenyamanan, aksesibilitas, dan keindahan hendaknya menjadi acuan dalam pemenuhan kriteria ruang publik yang baik. Terdapat beberapa komponen penting yang diatur untuk mencapai kualitas ruang publik diantaranya: vegetasi, penerangan, pembatas sub-ruang, jalur pejalan, pagar, tangga/ramp, penutup permukaan, signage, fasilitas aktifitas aktif, tempat duduk, tempat sampah, jalur masuk, elemen air. Dengan pembentukan indikator secara normatif tersebut maka diharapkan konsep revitalisasi Citra Niaga dapat berjalan dengan tepat sasaran, sehingga Citra Niaga dapat kembali diterima masyarakat Kota Samarinda sebagai salah Ruang Publik yang menjadi ikon Kota Samarinda

\section{Saran}

Idealnya sebagai seorang arsitek dalam merancang suatu ruang publik hendaknya memegang norma dan aturan didalam perancangannya. Ruang publik yang merupakan kebutuhan penting masyarakat haruslah memenuhi standar yang ditentukan agar mampu diterima dengan baik dihati masyarakat. Arsitek sebagi seorang yang mampu menganalisa dan memberikan gagasan perancangan terhadap ruang publik hendaknya memiliki pemahaman yang baik terhadap pembentukan suatu ruang publik; karakter masyarakat, kemauan masyarakat, serta standar normatif terkait; keamanan, keselamatan, kesehatan, daya tarik, kenyamanan, aksesibilitas, dan keindahan haruslah menjadi acuan didalam perancangan ruang publik karena hal tersebut 
berkaitan dengan cita-cita masyarakat sendiri selaku pengguna.

\section{Daftar Pustaka}

Carr, Stephen. (1992). Public Space, Cambridge University Press. Cambridge.

Darmawan, Edy. (2005). Ruang Publik dan Kualitas Lingkungan. Seminar Nasional Pesat Gunadarma, Jakarta.

Dimastanto, Adriadi. (2008). PrinsipPrinsip Perancangan Taman Lingkungan Studi Kasus : Taman Lesmana dan Taman Pendawa. Tugas Akhir, Institut Teknologi Bandung, Jawa Barat.

Hidayati, Zakiah, Redesain Area Pkl Dijalan Niaga Selatan Kawasan Citra Niaga. Poltek, Samarinda.
Kompas. (2000) Citra Niaga Samarinda Memudarnya Citra Aga Khan Award.

Kosla, Roni. (1989). Technical Reviuw Summary. Citra Niaga Urban Development, Samarinda.

Widjaja, Martokusumo. "Revitalisasi, Sebuah Pendekatan Dalam Peremajaan Kawasan”. Jurnal Perencanaan Wilayah dan Kota, Vol.19/No.3, Desember 2008, hal 57-73.

Zahnd, M. (1999) Perancangan Kota Secara Terpadu, Soegijapranata University Press, Semarang. 